\title{
Purulent pericarditis and mediastinal abscess in a young infant
}

\author{
Khuen Foong Ng ำ, ${ }^{1}$ Ashanti Sham Bala Krishnan, ${ }^{1}$ Gregory J Skinner, ${ }^{2}$ \\ Premkumar Christian Bakia Sundaram ${ }^{1}$
}

${ }^{1}$ Paediatrics, University Hospitals of Leicester NHS Trust, Leicester, UK

${ }^{2}$ Paediatric Cardiology, University Hospitals of Leicester NHS Trust, Leicester, UK

\section{Correspondence to \\ Dr Khuen Foong Ng; khuenfoong.ng@nhs.net}

KFN and ASBK contributed equally.

KFN and ASBK are joint first authors.

Accepted 1 July 2020

\section{DESCRIPTION}

A thriving, previously healthy 3-month-old girl presented with a 4-day history of fever, irritability and poor feeding. On admission, she was tachycardic, had cool peripheries with normal central perfusion, pulse volume and blood pressure. There was no obvious source of infection from clinical examination. Single-bottle blood culture sampling and lumbar puncture were done prior to commencement of ceftriaxone.

Initial blood test revealed an elevated C-reactive protein (CRP) at $214 \mathrm{mg} / \mathrm{L}$ and leucocytosis $\left(30.7 \times 10^{9} / \mathrm{L}\right)$, predominantly neutrophils $\left(22.5 \times 10^{9} / \mathrm{L}\right)$, with normal cerebrospinal fluid (CSF) analysis. Blood and CSF cultures were negative. Urine culture grew multiresistant Escherichia coli but it was a contaminated sample with the presence of numerous epithelial cells. Chest X-ray (CXR) was initially reported as normal with prominent thymus.

The patient remained febrile $\left(38^{\circ} \mathrm{C}-39.4^{\circ} \mathrm{C}\right)$, irritable, persistently tachycardic (160-200 beats/ $\mathrm{min})$ and tachypnoeic $(57 \pm 11$ breaths/min) with increasing CRP (highest at $279 \mathrm{mg} / \mathrm{L}$ ) and leucocytosis (highest white cell count at $43.9 \times 10^{9} / \mathrm{L}$ ) despite 48 hours of antibiotic treatment. An abdominal ultrasound did not show abnormalities. Besides sinus tachycardia, electrocardiogram was normal. Echocardiography was requested for possible atypical Kawasaki disease and it demonstrated a large echogenic pericardial effusion with fibrous strands, indicative of purulent pericarditis, along with evidence of impending temponade (figure 1). It was thought that the initial CXR actually showed

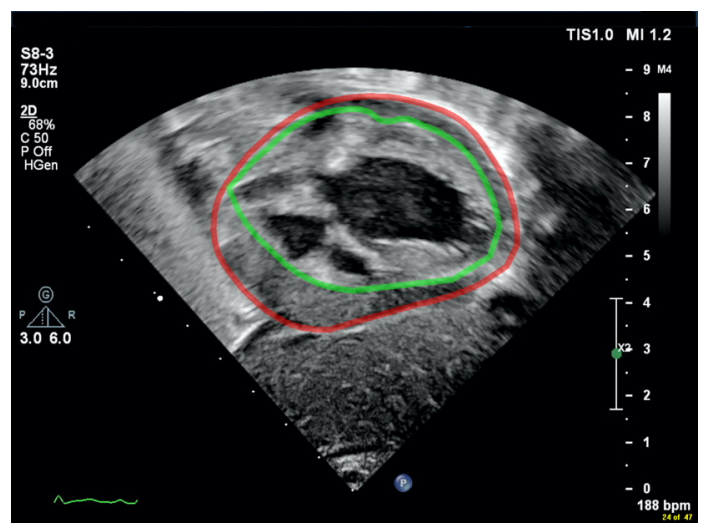

Figure 1 Large echogenic pericardial effusion with fibrous strands in echocardiography image. Green and red lines indicate visceral and parietal pericardium, respectively.

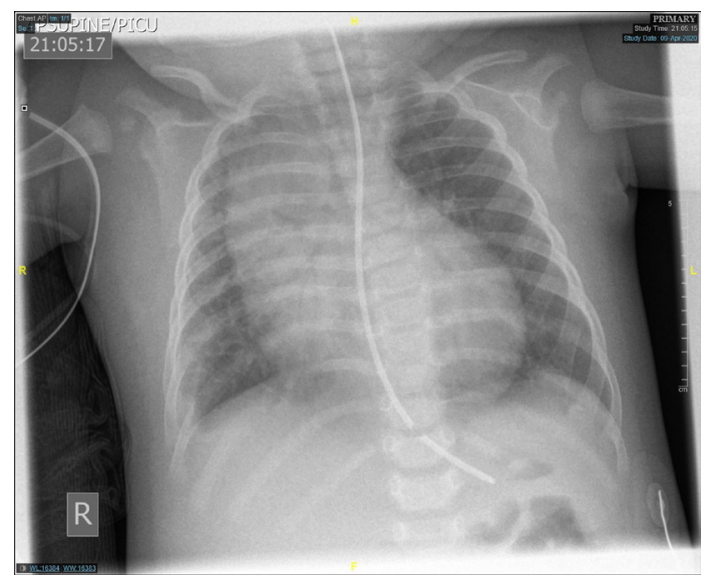

Figure 2 Second chest X-ray showed widened mediastinum, globular heart, right chest wall swelling and right pleural effusion.

widened mediastinum in addition to prominent thymus. This was confirmed with a second CXR which also revealed globular heart, right chest wall swelling and right pleural effusion (figure 2). The patient subsequently underwent midline sternotomy for surgical drainage. Intraoperative findings revealed large purulent pericarditis and superior mediastinal abscess which extended into the apex of the right lung, the base of the neck along the pretracheal fascia and the right pleural space. The thymus gland was tensed and infiltrated with pus.

Postoperative computerised tomography (CT) showed a residual rim enhancing abscess in the right superior mediastinum and extensive thrombus in the extracranial right internal jugular vein, indicative of a Lemierre-like syndrome. ${ }^{12}$ CT scan of the head and neck did not demonstrate any infective focus which may have contributed to the diagnosis. Pus culture grew Panton-Valentine leucocidinproducing methicillin-sensitive Staphylococcus aureus.

Intravenous flucloxacillin and clindamycin were given for 4 weeks followed by 2 weeks of oral flucloxacillin with significant clinical and laboratory improvement. Enoxaparin was initiated for a minimum of 6 weeks. Lymphocyte subsets, dihydrorhodamine test, immunoglobulin levels and human immunodeficiency virus (HIV) test did not identify any underlying immunodeficiency.

Purulent pericarditis and mediastinal abscess are very rare $^{3} 4$ especially in previously healthy children. Infective mediastinitis usually occurs as a result of post-sternotomy complication or due to 
descending infection from deep neck abscess (eg, peritonsillar, parapharyngeal, retropharyngeal abscesses) and odontogenic infection. ${ }^{45}$ Common aetiologies of bacterial pericarditis in childhood include $S$. aureus, Mycobacterium tuberculosis (especially in tuberculosis endemic countries), Streptococcus (eg, pneumococcus, group A Streptococcus), Haemophilus, Salmonella, meningococcus and Mycoplasma. Purulent pericarditis is a life-threatening condition with increased risk of constrictive pericarditis. ${ }^{6}$ Treatment delay has been associated with high mortality due to cardiac tamponade. ${ }^{6}$ Clinical features

\section{Learning points}

- Patients with unexplained clinical signs and symptoms who are not responding to seemingly appropriate treatment should always be carefully reassessed to look for alternative diagnosis, so that any underlying sinister condition is not missed.

- In a young infant with clinical and laboratory evidence of serious bacterial infection without other apparent source of infection, widened mediastinum may represent mediastinal abscess and globular heart shape may indicate purulent pericarditis.

- Purulent pericarditis must be treated aggressively and promptly because it is a life-threatening condition with high risk of mortality and constrictive pericarditis. of purulent pericarditis include chest pain, tachycardia (out of proportion to the degree of fever), hypotension, pulsus paradoxus tachypnoea and pericardial friction rub.

Contributors KFN and ASBK prepared the manuscript. PCBS and GJS reviewed the article prior to submission. All authors approved the draft.

Funding The authors have not declared a specific grant for this research from any funding agency in the public, commercial or not-for-profit sectors.

Competing interests None declared.

Patient consent for publication Parental/guardian consent obtained.

Provenance and peer review Not commissioned; externally peer reviewed.

\section{ORCID iD}

Khuen Foong Ng http://orcid.org/0000-0002-8767-3974

\section{REFERENCES}

1 Van Hoecke F, Lamont B, Van Leemput A, et al. A Lemierre-like syndrome caused by Staphylococcus aureus : an emerging disease. Infect Dis 2020;52:143-51.

2 Root RW, Barrett TW, Abramo TJ. A 10-month-old with Lemierre syndrome complicated by purulent pericarditis. Am J Emerg Med 2013;31:274.e5-274.e7.

3 Lutmer JE, Yates AR, Bannerman TL, et al. Purulent pericarditis secondary to community-acquired, methicillin-resistant Staphylococcus aureus in previously healthy children. A sign of the times? Ann Am Thorac Soc 2013;10:235-8

4 Wilson CD, Kennedy K, Wood JW, et al. Retrospective review of management and outcomes of pediatric descending mediastinitis. Otolaryngol Head Neck Surg 2016;155:155-9.

5 Shah SS, Lautenbach E, Long CB, et al. Staphylococcus aureus as a risk factor for bloodstream infection in children with postoperative mediastinitis. Pediatr Infect Dis J 2005;24:834-7.

6 Adler Y, Charron P, Imazio M, et al. 2015 ESC guidelines for the diagnosis and management of pericardial diseases. Eur Heart J 2015:36:2921-64.

Copyright 2020 BMJ Publishing Group. All rights reserved. For permission to reuse any of this content visit

https://www.bmj.com/company/products-services/rights-and-licensing/permissions/

BMJ Case Report Fellows may re-use this article for personal use and teaching without any further permission.

Become a Fellow of BMJ Case Reports today and you can:

- Submit as many cases as you like

- Enjoy fast sympathetic peer review and rapid publication of accepted articles

- Access all the published articles

- Re-use any of the published material for personal use and teaching without further permission

Customer Service

If you have any further queries about your subscription, please contact our customer services team on +44 (0) 2071111105 or via email at support@bmj.com.

Visit casereports.bmj.com for more articles like this and to become a Fellow 